\title{
Detection of Brucella Abortus in Caprine and Ovine by Real-Time PCR Assay
}

\author{
Muhammad Bilawal Arain ${ }^{1}$, Abdullah Babar ${ }^{1}$, Muhammad Ibrahim Panhwar², Khush Hal ${ }^{1}$, \\ Muhammad Mubashir Farooq ${ }^{1}$, Zainab Lanjar ${ }^{3}$, Ali Gul Soomro ${ }^{1}$, Saqib Ali Fazilani ${ }^{4}$, \\ Muhammad Naeem Jan ${ }^{1}$, Loveson Lakhani ${ }^{1}$, Adnan Yousaf ${ }^{1, ~ *, ~ I n a y a t u l l a h ~ S a r k i ~}{ }^{1}$, \\ Rehana Shahnawaz ${ }^{1}$, Mathan ${ }^{5}$ \\ ${ }^{1}$ Faculty of Animals Husbandry and Veterinary Science, Sindh Agriculture University, Tandojam, Pakistan \\ ${ }^{2}$ Department of Animal Breeding and Genetics, Faculty of Animal Production and Technology, Shaheed Benazir Bhutto University of \\ Veterinary and Animal Sciences (SBBUVAS), Sakrand, Pakistan \\ ${ }^{3}$ Department of Microbiology, Faculty of Veterinary Science, Shaheed Benazir Bhutto University of Veterinary and Animal Sciences \\ (SBBUVAS), Sakrand, Pakistan \\ ${ }^{4}$ Department of Pharmacology and Toxicology, Faculty of Bioscience, Shaheed Benazir Bhutto University of Veterinary and Animal Sciences \\ (SBBUVAS), Sakrand, Pakistan \\ ${ }^{5}$ College of Animal Science and Technology, Yangzhou University, Yangzhou, China
}

Email address:

dr.adnan011@gmail.com (A. Yousaf)

*Corresponding author

\section{To cite this article:}

Muhammad Bilawal Arain, Abdullah Babar, Muhammad Ibrahim Panhwar, Khush Hal, Muhammad Mubashir Farooq, Zainab Lanjar, Ali Gul Soomro, Saqib Ali Fazilani, Muhammad Naeem Jan, Loveson Lakhani, Adnan Yousaf, Inayatullah Sarki, Rehana Shahnawaz, Mathan. Detection of Brucella Abortus in Caprine and Ovine by Real-Time PCR Assay. Animal and Veterinary Sciences.

Vol. 9, No. 5, 2021, pp. 141-144. doi: 10.11648/j.avs.20210905.13

Received: September 4, 2021; Accepted: September 22, 2021; Published: October 21, 2021

\begin{abstract}
A molecular research was carried out in the areas of Lahore in order to confirm the existence of B. abortus antigen in Caprine and ovine by utilizing molecular techniques in this study. Small ruminants can be infected with B. abortus (the causative agent of bovine brucellosis), which complicates brucellosis control efforts because most brucellosis control programmes rely on immunological testing rather than genomic testing to determine the specific species circulating in ruminants. Now at this investigation, $n=1270$ goat serum samples and $n=770$ sheep serum samples were collected, respectively. After already being tested with the Rose Bengal test, all positive specimens were examined to the real-time PCR technique. RBT confirmed brucellosis prevalence of $21.43 \pm 0.37 \%$ and $18.11 \pm 0.12$ in caprine and ovine respectively. Out of 230 positive goat samples, real-time PCR found B. abortus in 150 samples $(65.21 \pm 0.51)$ in sheep and goats and 118 samples $(71.51 \pm 0.21 \%)$ out of 165 seropositive sheep samples. Brucella abortus infection in small ruminants could be caused by a combination of factors including mixed farming of small and large ruminants, sharing of the same pasture, and the presence of reservoir hosts on a farm, all of which could be risk factors for Brucella species cross-infection in non-species hosts. It has been determined that B. abortus is the causative agent of caprine and ovine brucellosis in the country of Pakistan. Results of this study can be utilised to develop successful brucellosis eradication and control strategies in small ruminants, which can be applied to other animals.
\end{abstract}

Keywords: Brucella Abortus, Sheep, Goat, Real-time PCR, RBPT

\section{Introduction}

Brucellosis is a serious zoonotic disease that affects both humans and livestock [23]. The disease's eradication and control are critical for public health [10]. However, during the previous few years, its frequency has been steadily increasing [3]. Although Brucellosis has been 
eradicated in affluent countries, it continues to be a problem in tropical and underdeveloped nations [17]. It's also common in Pakistan [1]. Mix farming and housing of small and large ruminants in tropical settings with no strict biosafety procedures may result in cross transmission of Brucella species to their non-preferred host, complicating brucellosis management strategies [24]. Brucella comes in eleven different species [25]. Each species has a favorite host [23]. Brucella pathogen phenotype isolates have been known to have host specificity in the past [9]. However, due to mixed farming, sharing of the same pasture by small and large ruminants, mixed livestock shelters, the presence of reservoir hosts in a farm, and uncontrolled animal movements, Brucella species may cross infect their non-preferred hosts [25]. The Brucella's eco-plasticity and polypathogenicity allow it to breach the species barrier [26]. This type of transmission is known as inter-species transmission, and it is the primary barrier to brucellosis control and eradication [3]. Even farm dogs might be carriers of brucellosis on the farm [5]. B. abortus can be transmitted not just by dogs, but also by wild animals, cats, and Chinese water deer [20]. Brucellosis has also been documented in avian species [14]. Antibodies to the Brucella infection were found in chickens kept on a seropositive farm [7]. Brucellosis control and eradication are mostly based on stringent implementation of test and slaughter policies, movement control, sanitation, and vaccination, however cross-species transmission can be a cause of vaccination failure [4]. The detection of Brucella species in small and large ruminants, reservoir hosts, fomites, and wild life species is critical for effective control and eradication methods to be implemented [13]. In field conditions, it is critical to inspect the Brucella for non-preferred host species. Interspecies transmission of Brucella, which can occur spontaneously and produce clinical disease in non-preferred hosts, is also a pressing need for time [11]. The goal of this work was to determine brucellosis seroprevalence in small ruminants and to use a real-time PCR test to detect B. abortus in sheep and goats.

\section{Materials and Method}

Blood samples were taken from $\mathrm{n}=770$ sheep and $\mathrm{n}=$ 1270 goats utilizing a practical collection approach [2]. These herds' small ruminants also had mixed farming, pasture sharing, shared habitation, a history of abortion, and close contact with seropositive large ruminants. The serum was isolated and stored at $-20^{\circ} \mathrm{C}$ after the blood samples were taken in a vacutainer without anticoagulant.
The Rose Bengal antigen was received from the SB Lab Rawalpindi and used to serologically screen all samples [6]. Exgene ${ }^{\mathrm{TM}}$ Blood SV-mini Kit (Gene ALL ${ }^{\circledR}$ Biotechnology Co. Ltd, Songpa-gu, Korea) was used to extract DNA from all seropositive samples, as directed by the manufacturer. After quantification, genomic samples were stored at $-20^{\circ} \mathrm{C}$ until further research. Real-Amp ${ }^{\mathrm{TM}}$ SYBR qPCR master mix (Cat\# 801-020, Gene ALL ${ }^{\circledR}$ Biotechnology Co. Ltd, Songpagu, Korea) was used for genomic amplification. For amplification, a reaction mixture of $20 \mu \mathrm{L}$ was employed, including $4 \mu \mathrm{L}$ of master mix, $0.5 \mu \mathrm{L}(500 \mathrm{nmol})$ of each species specific primer [15] forward: 5 ' CCATTGAAGTCTGGCGAGC 3 ' and reverse: 5 ' CGATGCGAGAAAACATTGACCG 3 ', $1 \mu \mathrm{L}$ of DNA, and $14 \mu \mathrm{L}$ of nuclease free water. Positive was defined as a cycle threshold (Ct-value) of less than 40. As a positive control, a reference strain of B. abortus (BA544) was received from the SB Lab Rawalpindi, Pakistan. Amplification of required DNA was performed in a 96well micro plate (Thermo Fischer Scientific Inc., Waltham, USA) using an ABI 7500 Real Time PCR System. Denaturation at $94^{\circ} \mathrm{C}$ for 10 minutes, then 40 cycles of denaturation at $95^{\circ} \mathrm{C}$ for 10 seconds, annealing at $60^{\circ} \mathrm{C}$ for 10 seconds, and extension at $72^{\circ} \mathrm{C}$ for 10 seconds. The last extension took 3 minutes at $72^{\circ} \mathrm{C}$. At each extension stage, fluorescent dye coupled with SYBR green-I was used to detect the double-stranded PCR result. Through computerized software, an amplification curve of PCR product was examined and recorded.

\section{Statistical Analysis}

Statistical Package for Social Science was used to analyses the data and estimate the odds ratio (95\% confidence interval) (SPSS for Windows version 20, SPSS Inc., Chicago, IL, USA). The $\mathrm{SE}_{\mathrm{P}}$ formula was used to compute the standard error sample proportion of standard deviation.

$$
\mathrm{SE}_{\mathrm{P}}=\text { square } \operatorname{root}[\mathrm{P}(1-\mathrm{P}) / \mathrm{n}]
$$

\section{Results and Discussion}

RBPT revealed that $230(18.11 \pm 0.12 \%)$ goat serum samples out of 1270 and $165(21.43 \pm 0.37 \%)$ sheep serum samples out of 770 were seropositive. The PCR product size of B. abortus was found to be $156 \mathrm{bp}$ after quantitative PCR, confirming that B. abortus was present in 150 samples $(65.21 \pm 0.51 \%)$ out of 230 seropositive samples in goats and 118 samples $(71.51 \pm 0.21 \%)$ out of 165 seropositive samples in sheep (Table 1).

Table 1. Diagnostic Value Comparison of RBPT with PCR for Detection Brucella Species.

\begin{tabular}{lllll}
\hline Diagnostic Tests & Species & No of Sample & Positive & (\%) \\
\hline \multirow{2}{*}{ RBPT } & Goats & 1270 & 230 & 18.11 \\
& Sheep's & 770 & 165 & 21.43 \\
\multirow{2}{*}{ PCR } & Goats & 230 & 150 & 65.21 \\
& Sheep's & 165 & 118 & 71.51 \\
\hline
\end{tabular}


The disease is ubiquitous not only in ruminants but also in soil [2]. The current investigation was done in the Lahore area. Previously, PCR assays revealed B. abortus biovar-1 in $86 \%$ of goat blood samples and $64 \%$ of goat milk samples [12]. In ewes in Nigeria, an abortion caused by B. abortus was confirmed. The cross-species transmission was confirmed when the same Brucella biovar was recovered from cattle kept in close contact with sheep [16]. [8] used serum samples from slaughtered goats. They discovered B. abortus in $12.03 \%$ of the samples. It was owing to the grazing habits of cattle in Nigeria, where they share pasture with sheep and goats. Despite a brucellosis eradication attempt in Egypt, the disease was widespread in animals. B. abortus infection of nonpreferred hosts by cattle was discovered in this investigation. Close farming could be a risk factor for brucellosis infection in cattle, buffalo, sheep, and goats [22]. In a previous investigation in Pakistan, all seropositive blood samples from small ruminants were found to be positive for B. abortus by real-time PCR, but no B. melitensis was found. The bacteria B. abortus has been discovered as a cause of abortion in small ruminants [3]. There could be a lot of risk factors that have a role in cross-species infection. For effective planning, these risk variables should be examined. This could be the main reason for control failure in a country like Pakistan, where there are no strong biosafety procedures in place. Mixed farming, in which small and large animals share the same pasture, could be the source of B. abortus transmission to small ruminants. The infection may be secreted by animals [18]. Brucella might live in soil and other fomites for a long time [1]. In a mixed agricultural system, the same housing and presence of seropositive animals in the herd could play a role in transmission [3]. The role of ecto-parasites in Brucella transmission has lately been explored. Brucella transmission is also aided by ticks, mites, and lice [21]. The examination of Brucella species cross transmission should include these ectoparasites with fomites, water, and soil. Brucellosis is on the rise as a result of Brucella species infecting their non-preferred hosts. On a serogical basis, abortion caused by B. abortus in small ruminants cannot be recognized. Serological-based screening could lead to erroneous control programme planning. Brucella species specific identification is important in management efforts [19]. Early and precise detection of Brucella species and biovar/biotypes is critical for brucellosis control and eradication.

\section{Conclusion}

Previous research had devoted little attention to interspecies transmission. The molecular assay was employed in this investigation to confirm the presence of B. abortus in sheep and goats. It's possible that B. abortus is a problem for small ruminants.

\section{Conflict of Interest}

The authors declare that they have no competing interests.

\section{References}

[1] Ahmad, T., Khan, I., Razzaq, S., Khan, S. H. and Akhtar, R., (2017). Prevalence of Bovine Brucellosis in Islamabad and Rawalpindi Districts of Pakistan. Pakistan J. Zool., 49: 11231126. https://doi.org/10.17582/journal.pjz/2017.49.3.sc5

[2] Ahmed, R., Muhammad, K., Rabbani, M. and Khan, M. S., (2017). Seroprevalence and Associated Risk Factors of Bovine Brucellosis in District Gujranwala, Punjab, Pakistan. Pakistan J. Zool., 49: 1739-1748. https://doi.org/10.17582/journal.pjz/2017.49.5.1739.1748

[3] Ali, S., Akhter, S., Neubauer, H., Melzer, F., Khan, I., Ali, Q. and Irfan, M., (2015). Molecular Identification of Bovine Brucellosis Causing Organisms at Selected Private Farms in Pothohar Plateau, Pakistan J. Infect. Devel. Ctries., 9: 470475. https://doi.org/10.3855/jidc.5110

[4] Akhtar, R., Anwar, M., Khan, I., El-Adawy, H., Aslam, A., Mustafa, G., Rehmani, S., Saleem, M. and Naz, S., (2017). Pathological Investigations of Organ Affinity of Brucella Species and their Cross Species Transmission. Pak. Vet. J., 37: 372-374.

[5] Baek, B., Lim, C., Rahman, M., Kim, C. H., Oluoch, A. and Kakoma, I., (2003). Brucella abortus infection in indigenous Korean dogs. Can. J. Vet. Res., 67: 312-314.

[6] Baloch, A. S., Rasheed, A., Rind, R., Sahito, J. K., Buriro, R. Ayoob, M. F. and Dewani, P., (2017). Seroprevalence of Brucellosis in Camels in Sindh Pakistan. Pakistan J. Zool., 49: 367-369. http://dx.doi.org/10.17582/journal.pjz/2017.49.1.sc5

[7] Cadmus, S., Adesokan, H., Oluwayelu, D., Idris, A. and Stack, J., (2010). Brucella Abortus Antibodies in the Sera of Indigenous and Exotic Avian Species In Nigeria. Anim. Hlth. Prod., 58: 382-384.

[8] Junaidu, A., Daneji, A., Salihu, M., Magaji, A., Tambuwal, F., Abubakar, M. and Nawawi, H., (2010). Evidence of Brucella abortus in Non-Preferred Caprine and Ovine Hosts by Realtime PCR Assay. Curr. Res. J. biol. Sci., 2: 275-277.

[9] Khan A, Rind R, Shoaib M, Kamboh AA, Mughal GA, Lakho SA, Malhi KK, Nizamani AR, Yousaf A (2016). Isolation, identification and antibiogram of Escherichia coli from table eggs. J. Anim. Health Prod. 4 (1): 1-5 http://dx.doi.org/10.14737/journal.jahp/2016/4.1.1.5

[10] Habib F, Jabbar A, Shahnawaz R, Memon A, Yousaf A, Bilal M, Jamil T, Khalil R and Sharif A (2019). Prevalence of hemorrhagic septicemia in cattle and buffaloes in Tandojam, Sindh, Pakistan. Online J. Anim. Feed Res., 9 (5): 187-190. https://dx.doi.org/10.36380/scil.2019.ojafr26

[11] Hussain A, Yousaf A, Mushtaq A. (2018) Prevalence of mycoplasma gallisepticum in ross-308 broiler breeder through the contrast of serological assessments in Pakistan. J Dairy Vet Anim Res. 7 (1): $00185 . \quad$ https://dx.doi.org 10.15406/jdvar.2018.07.00185

[12] Leal-Klevezas, D. S., Martí nez-Vázquez, I. O., Garcí aCantú, J., López-Merino, A. and Martí nez-Soriano, J. P., (2000). A nested PCR assay for the detection of Mycoplasma hyopneumoniae in tracheobronchiolar washings from pigs. Vet. Microbiol., 75: 9197. https://doi.org/10.1016/S0378-1135(00)00200-5 
[13] Muendo, E. N., Mbatha, P. M., Macharia, J., Abdoel, T. H., Janszen, P. V., Pastoor, R. and Smits, H. L., (2012). Infection of cattle in Kenya with Brucella abortus biovar 3 and Brucella melitensis biovar 1 genotypes. Trop. Anim. Hlth. Prod., 44: 17-20. https://doi.org/10.1007/s11250-011-9899-9

[14] Mushi, E., Binta, M., Basupang, K. and Samakabadi, E., (2008). Brucella abortus antibodies in the sera of indigenous chickens around Gaborone, Botswana. J. Anim. Vet. Adv., 7: 1610-1612.

[15] Newby, D. T., Hadfield, T. and Roberto, F. F., (2003). RealTime PCR Detection of Brucella abortus: a Comparative Study of SYBR Green I, 5'-Exonuclease, and Hybridization Probe Assays. Appl. environ. Microbiol, 69: 4753-4759. https://doi.org/10.1128/AEM.69.8.4753-4759.2003

[16] Ocholi, R., Kwaga, J., Ajogi, I. and Bale, J., (2005). Animal and human influenzas. Rev. Scient. Tech. Off. Int. Epizoot., 24: 973-979. https://doi.org/10.20506/rst.24.3.1627

[17] Pappas, G., Papadimitriou, P., Akritidis, N., Christou, L. and Tsianos, E. V., (2006). The new global map of human brucellosis. Lancet Infect. Dis., 6: 91-99. https://doi.org/10.1016/S1473-3099(06)70382-6

[18] Samad, A., Abbas, F., Ahmad, Z., Pokryrshko, O. and Asmat, T. M., (2018). Comparison of infectivity and productivity of Steinernem feltiae and Heterorhabditis bacteriophora in Galleria mellonella and Tenebrio molitor Pakistan J. Zool., 50: $1597-1600$. $\mathrm{pjz} / 2018.50 .4 . \mathrm{sc} 17$

[19] Shahzad, A., Neubauer, H., Melzer, F., Khan, I., Akhter, S., Jamil, T. and Umar, S., (2017). Analysis of Morphometric Characteristics of Different Populations of Tabanus bromius Linne 1758 (Diptera: Tabanidae). Pakistan J. Zool., 49: 11111114. https://doi.org/10.17582/journal. pjz/2017.49.3.sc2
[20] Truong, L. Q., Kim, J. T., Yoon, B. I., Her, M., Jung, S. C. and Hahn, T. W., (2011). Prevalence of Hemoplasma Infection among Cattle in the Western Part of Japan. J. Vet. med. Sci., 73: 1597-1601. https://doi.org/10.1292/jvms.11-0222

[21] Wang, Q., Zhao, S., Wureli, H., Xie, S., Chen, C., Wei, Q., Cui, B., Tu, C. and Wang, Y., (2018). Molecular detection of tick-borne pathogens harbored by ticks collected from livestock in the Xinjiang Uygur Autonomous Region, China. Ticks Borne Dis., 9: 1045-1048.

[22] Wareth, G., Melzer, F., Tomaso, H., Roesler, U. and Neubauer, H., 2015. Detection of Brucella abortus DNA in aborted goats and sheep in Egypt by real-time PCR. BMC Res. Notes, 8: 212. https://doi.org/10.1186/s13104-015-1173-1

[23] Yousaf, A., Khalil-Ur-Rahman, Shahnawaz, R. (2015) 'To evaluate the Sero-Occurrence of brucellosis in buffalo and goat through the contrast of serological assessments in Tandojam (Pakistan)', IOSR Journal of Agriculture and Veterinary Science, 8 (1): $45-46$. https://doi.org/10.9790/2380-08914546.

[24] Yousaf A, Laghari RA, Shoaib M, Ahmad A, Malhi KK, Mughal GA, Lakho S, Khetran IB (2016). The prevalence of brucellosis in Kundhi buffaloes in District Hyderabad, Pakistan. J. Anim. Health Prod. 4 (1): 6-8 http://dx.doi.org/10.14737/journal.jahp/2016/4.1.6.8

[25] Yousaf A, Abbas M, Laghari RA, Hassan J, Rubab F, Jamil T, Haider I, Abbas U, BiBi N. (2017). Epidemiological investigation on outbreak of brucellosis at private dairy farms of Sindh, Pakistan. Online J. Anim. Feed Res., 7 (1): 09-12.

[26] Yousaf A, Rais M-ul-N, Mushtaq A, Jamil T (2018). Prevalence of black quarter (BQ) disease in private dairy farm in Hyderabad, Sindh province of Pakistan. Online J. Anim. Feed Res., 8 (1): 01-04. 